\title{
AZ ÁLLAM ÚJRAFELFEDEZÉSE - ALKOTMÁNYOS VÁLTOZÁSOK MAGYARORSZÁGON
}

\author{
Varsányi Benedek \\ (Alkotmánybíróság)
}

(Prof. István Stumpf: Reinventing Government - Constitutional Changes in Hungary. Budapest, Gondolat, 2017., 212 oldal)

Magyarország új Alaptörvényének 2011-es elfogadása az azt övező és követő kiterjedt törvényi változásokkal együtt sikerrel pályázhatna Európában az elmúlt három évtized egyik legvitatottabb állami reformja minősítésre. A magyarországi jogszabályi változások számos eleme széles körú jogi és politikai kritikát kapott az Európai Unió és az Európa Tanács szerveitől, politikusoktól, civil szervezetektől és a tudományos élet képviselői részéről, itthon és külföldön egyaránt - a kritikus tanulmányok, jelentések és eljárások folyama a 2010 es parlamenti választások óta nem apadt el. Vajon ezek a magyarországi fejlemények a kormányzati rendszer innovatív átalakulásának hordozói, paradigmaváltást jeleznek az alkotmányosság felfogásában, avagy a demokratikus hanyatlás tünetei? Stumpf István könyve, a 2017. év végén megjelent Reinventing Government - Constitutional Changes in Hungary nem törekszik arra, hogy a fenti kérdésekre fekete-fehér válaszokat adjon. Ugyanakkor megbízható információkat és elemzéseket kínál, betekintést nyújt alkotmányjogi folyamatokba, ezáltal az olvasó egy összetettebb szempontrendszer alapján alkothat saját ítéletet és fogalmazhatja meg saját válaszait.

A kötet szinoptikus megközelítésü, ami a szerző többrétű szakértelmét és változatos tapasztalati hátterét tükrözi: a jogi szabályozási keretek leírása mellett értelmezi az Alkotmánybíróság döntéseit, ugyanakkor a jogi fejleményeket gyakran a tudományos és politikai viták kontextusában is kommentálja. Stumpf István az Alkotmánybíróság jelenleg leghosszabb ideje hivatalban lévő tagja, aki még 2010-ben, néhány hónappal a magyarországi alkotmányos változások kibontakozását megelőzően csatlakozott a testülethez. Alkotmánybírói megbízatását tehát még az előző Alkotmány hatálya alatt kezdte, majd aktívan részt vett az Alkotmánybíróság joggyakorlatának kialakításában az új Alaptörvényre való áttérés idején. Alkotmánybíróként számos politikai-jogi összecsapást megtapasztalt a parlamenti többség és az Alkotmánybíróság között, amelyek során az alkotmányos elvek és értékek - mint a hatalommegosztás és 
a jogállamiság - határozott védelmezőjeként lépett fel. Ugyanakkor a közigazgatás kutatójaként és egykori miniszterként figyelemmel van a hatékony kormányzás elveire, módszereire és gyakorlati igényeire is.

A Reinventing Government kötet a szerző által alkotmánybírói megbízatása alatt írt kilenc esszé gyüjteménye, három fejezetre tagolva. A gyújteményes jellegből következően a könyv minden esszéje egy önálló egészet alkot és a kötet más részeitől függetlenül is olvasható, ami lehetőséget ad az olvasónak, hogy érdeklődése szerinti sorrendben haladjon a kötetben. Ha úgy dönt, hogy a könyvet az elejétől kezdve a végéig egyben elolvassa, akkor időnként déjà vu érzése támadhat, mivel bizonyos témák (és néha még konkrét érvelések is) többször is visszatérnek különböző esszékben. Az ismétlődés oka - a könyv gyưjteményes jellege mellett - valószínúleg az, hogy egyes tárgykörök, mint például a bírósági aktivizmus, a hatalommegosztás, az 1989-90-es rendszerváltozás vagy a 2011-es alkotmányozás hangsúlyosan a szerző fókuszában álltak, s az elmúlt években több kontextusban is fontosnak tartotta ezek megvitatását. A kötet esszéi múfajukat tekintve színes képet mutatnak: néhány a szakirodalmi források széles skáláját idéző elméleti értekezés; mások egy alkotmányjogi kézikönyv részleteihez hasonlítanak, bőséges hivatkozással a tételes jogi szabályozásra és alkotmánybírósági esetekre; míg további esszékben a szerző kevésbé formális stílusban fejti ki gondolatait (ezek talán szóbeli előadások, beszédek írott változatai lehetnek).

A kötet fő állítása rögtön az első esszé címében megjelenik, egy kérdés formájában: „Miért van szükség erős, de alkotmányosan korlátozott államra?”. A szerző a könyv elején világosan megfogalmazza, hogy „erős, aktív és intelligens államra van szükség", amely megfelelő fékekkel és ellensúlyokkal van ellátva, hogy „ezek megakadályozzák az erős államot abban, hogy visszaéljen hatalmával" (a könyvnek az előbbi és a jelen írásban később előforduló idézett szövegrészeinek magyar fordítása tőlem - V. B.). A kötet összes esszéje valamilyen módon ehhez a tézishez kapcsolódik, ennek a problémának tárja fel különböző aspektusait.

A könyv a rivális good government és a good governance paradigmák összehasonlításával kezdődik. A szerző egyértelműen az első paradigma mellett foglal állást, azokra a feltételezésekre alapozva, amelyek szerint a piaci mechanizmusok (és a piaci logika szerint szervezett állam) nem képesek megfelelő jólétet, szolidaritást és társadalmi igazságosságot biztosítani, így az államnak korrigálnia kell a piaci mechanizmusokat - mind a közösség, mind pedig a piac javára. Ezen elmélet szerint ez a cél egy erős, centralizált állammal érhető el, egyértelmú felelősségi viszonyokkal és politikai elszámoltathatósággal. Van egy olyan közmenedzsment-reformmodell, amely összhangban van a good government paradigmával, nevezetesen a neowéberi állam (Neo-Weberian 
State, NWS), amely egyesíti új közmenedzsment (New Public Management, NPM) modelljének pozitív aspektusait a wéberi megfontolásokkal. A két paradigmának és a közmenedzsment-reformmodelleknek a megvitatása után a szerző felvázolja, hogy az Alaptörvény és annak módosításai milyen fontosabb változásokat vezettek be a magyar alkotmányos rendszerbe; kiemelve azokat a változásokat, amelyek befolyásolják az állam cselekvési képességét, továbbá azokat, amelyek a kormányzati hatalmat fékekkel és ellensúlyokkal korlátozzák. Az Alaptörvény elsődlegesen a Parlamentnél összpontosítja a hatalmat, miközben néhány olyan intézményt is létrehoz, amelyek egyes területeken korlátozzák a törvényhozás és a végrehajtó hatalom hatáskörét, nevezetesen a Költségvetési Tanácsot és az önálló szabályozó szerveket. Az alkotmányos rendszeren belüli legfontosabb kontrollmechanizmus az alkotmánybíráskodás, mivel az Alkotmánybíróság hatásköre (szúk kivételtől eltekintve) a jogalkotás minden területére kiterjed. Az ellensúlyozó hatás azonban ebben a vonatkozásban sem abszolút érvényü, mivel ha a kormánypártok kétharmados többséggel rendelkeznek a Parlamentben, akkor a végrehajtó és a törvényhozó hatalom alapvetően megegyezik az alkotmánymódosító hatalommal, amelynek nincs tételes alkotmányjogi korlátja.

A második esszé közelebb viszi az olvasót az Alaptörvényhez, feltárva létrehozásának okait, az alkotmányalkotás folyamatát és néhány olyan jogi és kulturális forrást, amelyre a dokumentumot építették. Itt a szerző az Alaptörvény bizonyos sajátos jellemzőit is kiemeli. Ezek közül az egyik a szöveg erős szimbolizmusa és értékorientációja, amely - amint később a könyvben látni fogjuk - releváns lesz a nemzeti identitás értelmezése szempontjából. A kötet itt újra áttekinti a hatalommegosztás rendszerét, majd továbblép az alkotmánybírósági felülvizsgálat és a jogértelmezési szabályok alapkérdéseire. Az Alaptörvény kiterjesztette az Alkotmánybíróság hatáskörét arra, hogy ne csak jogszabályi rendelkezéseket, hanem bírósági határozatokat is felülvizsgáljon (azaz a bírói értelmezésnek az Alaptörvénnyel való összhangját). Az Alaptörvény két külön cikkben ír elő értelmezési szabályokat, amelyek közül az első, az R) cikk (3) bekezdése csak önmagára az Alaptörvényre alkalmazandó, a második pedig más jogi aktusokra is vonatkozik. Érdemes megemlíteni, hogy a könyv megjelenése óta az utóbbi rendelkezést az Alaptörvény hetedik módosítása megváltoztatta. A 28. cikk előző változata úgy rendelkezett, hogy „[a] bíróságok a jogalkalmazás során a jogszabályok szövegét elsősorban azok céljával és az Alaptörvénnyel összhangban értelmezik. Az Alaptörvény és a jogszabályok értelmezésekor azt kell feltételezni, hogy a józan észnek és a közjónak megfelelő, erkölcsös és gazdaságos célt szolgálnak". A módosítás a fenti szabályokat kiegészítette egy új kisegítő szabállyal: „A jogszabályok céljának megállapítása során elsősorban a jogszabály preambulumát, illetve a jogszabály megalkotására vagy módosítására irányuló javaslat indokolását kell figyelem- 
be venni". Ez alapvetően azt jelenti, hogy most már mind az Alkotmánybíróság, mind más bíróságok számára előírás, hogy a jogszabályokat mintegy „originalista” módon értelmezzék, a jogalkotók eredeti szándékát követve.

A Jogállamiság, a hatalommegosztás, alkotmányosság címú harmadik esszé, amely ezeket a témákat a jogi és politikai alkotmányosság keretei között tárgyalja, a könyv egyik legizgalmasabb része. A szerző ebben az írásában viszszaviszi az olvasót az 1990-es évek elejére, amikor az Alkotmánybíróság a rendszerváltás idején a demokratikus átmenet kulcsszereplőjévé vált és a ,jjogállami forradalom" lezajlott. Első éveiben számos korabeli jogtudós szerint az Alkotmánybíróság aktivista megközelítést alkalmazott az Alkotmány értelmezését és a bíróság hatásköreit tekintve, ami - nézőponttól függően - egyes szakértők részéről méltatást, míg mások körében éles kritikát váltott ki. Az esszé bevezeti az olvasót ezekbe a vitákba, az aktivizmus különféle definícióit és mindkét oldal érveit bemutatva. Érdekes, hogy a szerző által idézett egyik jogtudós 1992-ben felhívta a figyelmet arra, hogy a magyar politikai rendszerben az alkotmánybírósági aktivizmussal kapcsolatos problémák elvezethetnek ahhoz a ponthoz, ahol az uralkodó politikai erôk megfontolják az alkotmánybírósági hatáskörök megnyirbálását. Ezek a tények elgondolkodó hátteret adnak az Alkotmánybíróság hatalmával és hatásköreivel kapcsolatos, 2010 utáni heves vitáknak. A szerző és más jogtudósok szerint a 2011-2012-es „alkotmányos forradalom" során a politikai alkotmányosság logikájának előretörését érhetjük tetten, szembeállítva az Európai Unió politikájának domináns logikájával, amely a politikai ügyeket is jogi problémákra fordítja le. Magyarországon a Parlament a politikai ügyek újrapolitizálására törekedett (beleértve az olyan ügyeket is, amelyeknek a politikai mellett jogi oldala is van). Ez a megközelítés természetszerúleg konfliktusokhoz vezetett az alkotmányos hatalmi rendszeren belül. 2011-2012-ben az Alkotmánybíróság határozatai egyértelmúen azt mutatták, hogy alkotmányos kontrollt gyakorol a törvényhozás felett. A helyzet 2012 végén, illetve 2013 elején éleződött ki, amikor az Alkotmánybíróság részlegesen megsemmisítette az Alaptörvény átmeneti rendelkezéseit. Ezt a döntést követte az Alaptörvény negyedik módosítása, amely kifejezetten megtiltotta az Alkotmánybíróságnak az Alaptörvény-módosítások felülvizsgálatát (az eljárást kivéve), jelezve a testületnek, hogy a Parlament kétharmados többsége nem fogad el korlátozásokat a hatalma gyakorlásában, és készen áll arra, hogy az Alkotmánybíróság döntéseit akár Alaptörvény-módosítás útján is felülbírálja.

A negyedik esszé az állam újrafelfedezésére, konkrétabban a magyarországi végrehajtó hatalomra összpontosít. A megelőző húsz év hagyományait követve az Alaptörvény megőrizte az alkotmányos berendezkedés alapjait: a parlamentáris kormányformát, amelyben a végrehajtó hatalom politikailag felelős a Parlamentnek. A szerző szerint a társadalmi és gazdasági kihívások, vala- 
mint a politika mediatizációja - a világ számos más országához hasonlóan Magyarországon is átalakította a végrehajtó hatalom múködésének természetét. Magyarország esetében ezek az alapul szolgáló folyamatok nem csak gyakorlati változásokhoz vezettek, hanem a jogi szabályozás révén is fokozták a kormányzat központosítását. Az Alaptörvény megerősítette a „kancellár-elv”et, azaz a miniszterelnök szerepkörét és politikai hatalmát. Ezzel párhuzamosan a vonatkozó törvények és kormányrendeletek a Miniszterelnöki Hivatalt a miniszterelnök munkaszervezetéből egy széles feladatkörrel rendelkező kormányzati hatalmi központtá alakították át. Ezek a változások a szerző álláspontja szerint egy prezidenciális rendszerré történő átalakulás csíráját is magukban hordozzák. A kötet a kormány és a központi közigazgatási szervek belső szerkezetéről is beszámol. Megjegyzendő, hogy a könyv megjelenése óta A központi államigazgatási szervekról, valamint a Kormány tagjai és az államtitkárok jogállásáról szóló 2010. évi XLIII. törvénynek a könyv által hivatkozott szabályait nagyrészt felváltotta a kormányzati igazgatásról szóló 2018. évi CXXV. törvény, azonban ez nem járt a bemutatott szabályozás tartalmának jelentős változásával.

A könyv második fejezetében található következő két esszé jelentősebb kitérőt tesz a központi alkotmányos intézményekhez kapcsolódó változásokra összpontosító előző fejezethez képest. Ezek az írások sajátosabb témákat dolgoznak fel: a tulajdonhoz való jogba történő állami beavatkozás alkotmányos korlátait és a magyar területi közigazgatás jellegzetességeit. Mindkét tanulmány a good government paradigma és az NWS modell megközelítésén alapul. Az első (azaz a könyvben az ötödik) esszé áttekintést ad az Alkotmánybíróságnak a tulajdonhoz való alapvető joggal kapcsolatos joggyakorlatáról a rendszerváltozástól az elmúlt évekig bezárólag, röviden bemutatva több mint egy tucat döntést. Itt teljesebb kontextus hiányában néha nehéz megragadni egyegy jogi probléma pontos lényegét, de az összefoglaló jó kiindulópontként szolgálhat a további olvasáshoz, ha az olvasónak valamely konkrétabb téma felkelti az érdeklődését. A fejezet következő esszéje a regionalizmus és az önkormányzatok vonatkozásában az elmúlt két évtizedben kidolgozott több reformtervet és ténylegesen elfogadott jogszabályokat is bemutatja, egészen a jelenleg múködő megyei kormányhivatalokig és járási hivatalokig. Ebből az írásból hiányolom annak értékelését, hogy a középszintű területi közigazgatás jelenlegi intézményi rendszere mennyiben felel meg a szerző által elfogadott minőségi, hatékonysági kritériumoknak; bár felvethető, hogy ennek kidolgozása további empirikus kutatást és olyan sok szempontú, részletes tárgyalást igényelne, amely nem illeszkedne a kötetbe.

A III. fejezetben A magyar Alkotmánybíróság helyzete Magyarország alkotmányos rendszerében címú hetedik esszé a kötet más részeiből már ismert témákat tárgyal: az Alkotmánybíróságnak a magyar alkotmányos fejlődés különböző 
szakaszaiban betöltött szerepét és az alkotmánybírósági aktivizmus problémáját. Említést érdemel, hogy a szerző ehelyütt rámutat arra, hogy az Alkotmánybíróság számos kritikusa félreértelmezte a "láthatatlan alkotmány" metaforáját, amelynek soha nem volt célja, hogy mintegy „örökkévalósági klauzula" szerepbe kerüljön, hogy olyan mércét képezzen, amely alapján az Alkotmánybíróság akár a tételes alkotmányt (illetve annak módosításait) is felülvizsgálhatná.

A nyolcadik esszé olyan témával foglalkozik, amelyre mostanában mind az európai politikában, mind a tudományos vitákban egyre nagyobb figyelem irányul: a „nemzeti identitás” (és az „alkotmányos identitás”) fogalmával, amely az Európai Unió intézményei jogi aktusainak a végrehajtásával összefüggésében van jelentősége. Az esszé végén lévő összefoglaló lényegében a bevezetést ismétli meg, és néhány ponton (mint az Alaptörvény negyedik módosításának megvitatása) az esszé elkalandozik a fő érvelési vonaltól, de egyébként átfogó bevezetést kínál a témához. Az 1960-as és 1970-es években az Európai Bíróság feltétlen érvényesülést megkívánó szabályként fejlesztette ki az uniós jog elsőbbségének elméletét, amely szerint az EU jogának és a nemzeti jognak az összeütközése esetén az uniós jog alkalmazását még egy tagállam alkotmánya sem ronthatta le. Ezen a téren a Lisszaboni Szerződés (amely módosította az Európai Unióról szóló szerződést) jelentős változást hozott, ugyanis kifejezett korlátot állított az uniós jog alkalmazása elé azáltal, hogy a tagállamok „nemzeti identitását” védelemben részesítette. A szerző hangsúlyozza, hogy ebben a körben gyakorlatilag az a legfontosabb kérdés, hogy melyik nemzeti vagy uniós - intézmény hatáskörébe tartozik annak eldöntése, hogy mi lehet része egy tagállam alkotmányos identitásának, mivel ezek a döntések vonják meg a tagállam autonómiájának határát. Határozott álláspontja szerint a tagállamok alkotmánybíróságai a leginkább kompetens intézmények saját nemzeti alkotmányos identitásuk értelmezésében; folyamatosan, költséghatékonyan és kellő előrelátással képesek arra, hogy védjék az országuk nemzeti érdekének legjelentősebb körét, mintegy moderátori szerepet betöltve a tagállami és az uniós jogalkotók párbeszédében, vitájában. A következő kérdés, hogyan kell ezt az értelmező munkát elvégezni, hogyan kell meghatározni az állam alkotmányos életének „sérthetetlen magját”. A szerző két fő iránymutatást nyújt ennek a feladatnak az elvégzéséhez. Először is, a konkrét alkotmányszöveg már önmagában is bőséges forrást kínál. Az Alaptörvény megszüntette a politikailag semleges alkotmányosság korszakát azáltal, hogy mind a Nemzeti Hitvallásban, mind a pedig tételes szabályokat tartalmazó rendelkezésekben számos karakteres érték mellett letette a voksot. Másodszor, az Alaptörvény rehabilitálta az úgynevezett történeti alkotmányt", ezzel megerösítette a jogi értelmezés történelmi perspektíváját, amelynek hagyományosan fontos szerepe volt a magyar jogi gondolkodásban. Mindkét elem hiteles ala- 
pot ad a nemzeti (alkotmányos) identitás kibontakozásához. A szerző által kinált értelmező iránymutatások összecsengenek az Alaptörvénnyel, amely az R) cikk (3) bekezdésében előírja, hogy „[a]z Alaptörvény rendelkezéseit azok céljával, a benne foglalt Nemzeti hitvallással és történeti alkotmányunk vívmányaival összhangban kell értelmezni". Az Alkotmánybíróság is ezekkel az iránymutatásokkal párhuzamosan járt el, amikor az Alaptörvény E) cikke (2) bekezdését értelmező 22/2016. (XII. 5.) AB-határozatban lefektette az alkotmányos önazonosság védelmének elveit („identitáskontroll”). Ebben a tárgykörben a könyv megjelenése óta az Alaptörvény hetedik módosítása jelentős változást hozott. A módosítás a fenti rendelkezést kiegészítette egy új szabálylyal, amely előírja, hogy az Európai Unió intézményei útján történő közös hatáskörgyakorlásnak „összhangban kell állnia az Alaptörvényben foglalt alapvető jogokkal és szabadságokkal, továbbá nem korlátozhatja Magyarország területi egységére, népességére, államformájára és állami berendezkedésére vonatkozó elidegeníthetetlen rendelkezési jogát". Bár az idézett rendelkezés szövege nem használja kifejezetten sem a nemzeti identitás sem az alkotmányos önazonosság fogalmakat, ha figyelembe vesszük a rendelkezés kontextusát és az Európai Unióról szóló szerződés 4. cikk (2) bekezdését, akkor nyilvánvaló, hogy a fenti norma az állami önrendelkezés „sérthetetlen magjának” meghatározására irányul.

A könyv kilencedik, utolsó esszéje az alkotmányos reformok politikai vetületét tárgyalja, különösen is ezeknek a bírósági függetlenséggel összefüggő aspektusait. A kelet-, illetve közép-európai alkotmánybíróságok fontos szerepet játszottak az 1990-es évek elején zajló demokratikus átmenetben. Két évtizedes stabil múködés után Magyarország és Lengyelország alkotmánybíróságai, illetve rendes bíróságai kihívásokkal találták szembe magukat az ország új politikai többsége felől. Ez az esszé is áttekinti a magyar alkotmánybíróság szerepét a demokratikus átmenetben, az alkotmánybírósági aktivizmus problémáját és a politikai alkotmányosság fogalmát, mint egy olyan megközelítési irányt, amely vezérlőelve lehet a 2010 utáni magyarországi és lengyel alkotmányos fejleményeknek. Itt az olvasó olyan, a könyv más részeiből visszatérő témákkal is találkozhat, mint a hatalommegosztás, az 1989-90-es rendszerváltozás, a 2010-es alkotmányozás, valamint a magyar Parlament és az Alkotmánybíróság közötti hatalmi küzdelmek. Hol húzódik a határvonal, ahol a demokrácia véget ér, és ahol már egy autoriter rendszer kezdődik? Nem könynyü pontosan kijelölni. Az egyik súlyos intő jel, ha a parlamenti többség elkezdi nyíltan figyelmen kívül hagyni az alkotmányba ágyazott normákat. Egy parlamentáris kormányformában a parlamenti többség hatalmának érdemi korlátját az alkotmánybíróság és a független bíróságok képezik. Magyarországon, ha egy politikai párt nagy többséggel nyer a parlamenti választásokon, könnyen válhat mind kormányzó, mind pedig egyúttal alkotmányozó több- 
séggé. Fogalmazhatunk úgy, hogy ez azt jelenti, hogy a magyar alkotmányos rendszer nem különösebben ellenálló, viszont rugalmassága megkönnyíti a minősített parlamenti többség számára, hogy politikai célkitűzéseit az Alaptörvény keretei között, a jogállamiság követelményét tiszteletben tartva valósítsa meg. Lengyelország alkotmányos szerkezete merevebbnek tûnik, nagyobb nyomásnak ellenállhat, de ez egy eltökélt politikai erőt arra is késztethet, hogy valamiképpen kijátssza vagy erélyesen megtörje azt. A szerző megjegyzi, hogy Magyarországon a parlamenti többség nem hajtott végre radikális reformokat az alkotmányvédelem és az igazságszolgáltatás intézményrendszere terén, bár néhány nem elhanyagolható változásra (főleg személyi jellegúekre) sor került. A lengyel igazságszolgáltatási rendszer függetlenségére nézve a szakértők ennél komorabb képet festenek. Mit tehetnek az alkotmánybíróságok politikailag kétséges helyzetekben, ahol a demokrácia megőrzése foroghat kockán? A szerző határozott válaszát akár alkotmánybírói hitvallásának is tekinthetjük: „a demokratikus válsághelyzetekben az alkotmánybíróságoknak hatáskörüket teljes terjedelemben gyakorolniuk kell annak érdekében, hogy megvédjék az állam alkotmányos alapjait, például a hatalommegosztás rendszerét, különösen is az igazságszolgáltatás függetlenségét, valamint mindazokat politikai jogokat és demokratikus intézményeket [...], amelyek lehetővé teszik a politikai rendszer demokratikus korrekcióját”. Azt is hozzáteszi: „[a]z alkotmánybíróságoknak azonban óvatosnak kell lenniük abban, hogy ne emeljék magukat az alkotmány, valamint a hatáskörüket és eljárásukat meghatározó érvényes szabályok felé - függetlenül attól, hogy ezzel milyen fontos ügyet szeretnének megvédeni -, mivel a korlátok túllépése ellentétes lenne a jogállamisággal, továbbá kártékony a jogállamiság és a demokrácia kultúrája szempontjából is (ami potenciálisan vissza is üthet egy későbbi időpontban). Ezen túlmenően a más hatalmi ágak hatáskörét sértő alkotmánybírósági aktivizmus a demokratikus folyamatokba történő közvetlen (és szándékos) beavatkozás túlkapásszerú eszközéül is szolgálhat ".

A könyv nem ad teljes képet Magyarország új Alaptörvényének minden egyes aspektusáról, még kevésbé az arra épülő jogrendszerről vagy a mindkettőt megalkotó parlamenti többség teljesítményéről. A szerző összegyüjtötte az alkotmányos rendszer válogatott elemeit, amelyeket alkotmánybíróként vagy kutatóként leginkább érdekesnek tartott. Ezek egy kirakós játék darabjai, amelyeket az olvasó felhasználhat saját képének kiegészítésére.

Megítélésem szerint a szerző a legtöbb érvét pontos jogi háttérrel és kiadós bibliográfiával támasztja alá. A könyv értékei közé tartozik, hogy a szerző erőfeszítéseket tesz az egymással versengő értékek megfontolására, mérlegelésére, és számos vitában mindkét oldal érveit feltárja; sőt, ezekkel összhangban már a könyv elején kifejezetten is leírja, hogy úgy véli, hogy „racionális vita során meg kell értenünk az egymással szembenálló álláspontokat, mielőtt el- 
utasítanák vagy támogatnák érveiket". Mindazonáltal nem fél attól sem, hogy kifejezze kétségtelen preferenciáját olyan értékek és eszmék iránt, mint a demokrácia, a jogállamiság, a közjó és a nemzeti érdek szolgálata, a good government paradigma és a neowéberi állammodell, csak hogy néhányat említsek. Sokszor szubjektív véleményét is megfogalmazza az általa tárgyalt témákról; nem érzem szükségét, hogy ezek bármelyikével vitába szálljak.

Stumpf István Reinventing Government - Constitutional Changes in Hungary címü könyve egy bennfentes tollából származó érdekfeszítő esszégyüjtemény, amely áttekintést nyújt a Magyarországon a közelmúltban zajlott alkotmányos változásokról, valamint bevezet az Alaptörvény szabályrendszerébe és a rendelkezések gyakorlati múködésének egyes részleteibe. Mindenekelőtt külföldi jogi kutatók és politikai elemzők számára tartogat hasznos ismereteket, de az ilyen területtel foglalkozó magyar szakemberek is újszerú gondolatokat és értékes elemzéseket találhatnak benne. 